\title{
Management of Type 2 Diabetes in the Primary Care Setting: A Practice-Based Research Network Study
}

Stephen J. Spann, $M D, M B A^{1}$

Paul A. Nutting, MD, MSPH ${ }^{2}$

James M. Galliber, $P b D^{3}$

Kevin A. Peterson, MD, MPH

Valory N. Pavlik, $P b D^{1}$

L. Miriam Dickinson, $P b D^{5}$

Robert J. Volk, $P b D^{1}$

${ }^{1}$ Department of Family and Community Medicine, Baylor College of Medicine,

Houston, Tex

${ }^{2}$ Center for Research Strategies, University

of Colorado, Denver, Colo

${ }^{3}$ American Academy of Family Physicians, and Department of Sociology, University of Missouri-Kansas City, Kansas City, Mo

${ }^{4}$ Department of Family Medicine and Community Health, University of

Minnesota, Minneapolis, Minn

${ }^{5}$ Departments of Family Medicine and Preventive Medicine and Biometrics, University of Colorado Health Sciences Center, Denver, Colo

\begin{abstract}
PURPOSE We wanted to describe how primary care clinicians care for patients with type 2 diabetes.

METHODS We undertook a cross-sectional study of 95 primary care clinicians and 822 of their established patients with type 2 diabetes from 4 practice-based, primary care research networks in the United States. Clinicians were surveyed about their training and practice. Patients completed a self-administered questionnaire about their care, and medical records were reviewed for complications, treatment, and diabetes-control indicators.
\end{abstract}

RESULTS Participating clinicians (average age, 45.7 years) saw an average of 32.6 adult patients with diabetes per month. Patients (average age, 59.7 years) reported a mean duration of diabetes of 9.1 years, with $34.3 \%$ having had the disease more than 10 years. Nearly one half $(47.5 \%)$ of the patients had at least 1 diabetes-related complication, and $60.8 \%$ reported a body mass index greater than 30. Mean glycosylated hemoglobin $\left(\mathrm{HbA}_{1 \mathrm{c}}\right.$ ) level was $7.6 \%$ (SD 1.73), and $40.5 \%$ of patients had values $<7 \%$. Only $35.3 \%$ of patients had adequate blood pressure control (<130/85 mm Hg), and only $43.7 \%$ had low-density lipoprotein cholesterol (LDL-C) levels $<100 \mathrm{mg} / \mathrm{dL}$. Only $7.0 \%$ of patients met all 3 control targets. Multilevel models showed that patient ethnicity, practice type, involvement of midlevel clinicians, and treatment were associated with $\mathrm{HbA}_{1 \mathrm{c}}$ level; patient age, education level, and practice type were associated with blood pressure control; and patient ethnicity was associated with LDL-C control.

CONCLUSIONS Only modest numbers of patients achieve established targets of diabetes control. Reengineering primary care practice may be necessary to substantially improve care.

Ann Fam Med 2006;4:23-31. DOI: 10.1370/afm.420.

\section{INTRODUCTION}

T 2002 , visits to primary care physicians accounted for $62.7 \%$ of all office visits in the United States, and diabetes mellitus ranked third, accounting for $3.1 \%$ of illness-related diagnoses. ${ }^{1}$ Patients with type 2 diabetes often have acute or chronic comorbid health problems that force the clinician to prioritize and address the most pressing or symptomatic problems first. ${ }^{2-6}$ The situation is further complicated by the lack of access to a complete multidisciplinary diabetes health care team or by the lack of systems within primary care practices to provide ongoing support for this chronic disease. ${ }^{7}$

In this article we describe the care provided by primary care clinicians to their patients who have type 2 diabetes using data from 3 sources: reports from physicians on their training and the patient care strategies they use to treat diabetes; surveys of patients about their diabetes care; and medical record reviews to determine medications used for diabetes and cardiovascular risk factor control, indicators of glycemic control, and diabetes-related com- 
plications. Our purpose was to describe the processes and outcomes of care of type 2 diabetes achieved by clinicians and their patients in member practices from 4 practice-based research networks (PBRNs). In particular, we examined practice design strategies for diabetes care, the composition of the health care team, the complexity of the health problems experienced by patients with type 2 diabetes (including comorbid conditions), control of diabetes (including cardiovascular risk-factor control), and the spectrum of treatment provided by their clinicians.

\section{METHODS}

\section{Settings}

The Diabetes Outcome Study was conducted in 4 primary care PBRNs in the United States from February 2001 to April 2002. PBRNs are collaboratives of physicians or clinics committed to performing research of importance and relevance to their clinical practice. ${ }^{8-11}$ The American Academy of Family Physicians National Research Network (AAFP-NRN), the Minnesota Academy of Family Physicians Research Network (MAFPRN), the Texas Academy of Family Physicians Research Network (TAFP R-Net), and the Southern Primary Care Urban Research Network (SPUR-Net) each recruited constituent members for the study. The AAFP-NRN is a nationally distributed network of primary care physicians. The MAFPRN and TAFP R-Net are statewide networks administered through their respective state AAFP chapters, and SPUR-Net is a partnership of primary health-care organizations located in Houston, Texas.

\section{Procedures}

For this study, the term primary care clinician is used to include family physicians, general practitioners, general internists, and nurse-practitioners. Recruitment of clinicians began in July 2000.

Participating clinicians and study coordinators were instructed to enroll 10 consecutive patients who met the eligibility criteria for the study. Patients were considered eligible if they (1) had a current diagnosis of type 2 diabetes (based on clinician judgment), (2) were at least 18 years of age, (3) were seeing their primary care clinician at the study visit, (4) had visited the study clinic at least once within past 2 years, and (5) were able to speak and read English. The institutional review boards of Baylor College of Medicine and the University of Minnesota approved the study.

\section{Measures}

Clinicians completed a self-administered questionnaire at the initiation of the study. This instrument included demographic characteristics of the clinician (age, sex, years in practice) and the practice (eg, location, spe- cialty, number of patients with diabetes seen in a typical month, specific practice management tools). ${ }^{12}$

After giving consent to participate in the study and before their outpatient clinic visit with the clinician, patients completed a self-administered questionnaire that solicited general demographic information and specific information about self-management of diabetes.

After the office visit, the study clinician or study coordinator completed a checklist of diabetes-related complications and clinical information from the patient's medical record, as well as the most recent laboratory values for glycosylated hemoglobin $\left(\mathrm{HbA}_{\mathrm{ic}}\right.$ and low-density lipoprotein cholesterol (LDL-C). Diabetes and cardiovascular risk-reduction medications were also abstracted.

\section{Control Targets}

The clinical indicators used were those defined by the Diabetes Quality Improvement Project from the National Committee for Quality Assurance (NCQA). ${ }^{13}$ The $\mathrm{HbA}_{1 \mathrm{c}}$ level was used as the primary indicator of diabetes control; a value $<7 \%$ indicated controlled, a value from $7.0 \%$ to $7.9 \%$ indicated intermediate control, and a value $\geq 8 \%$ indicated uncontrolled. These categories correspond to the 2002 clinical practice recommendations from the American Diabetes Association (ADA) ${ }^{14}$ and were used by Parnes et a ${ }^{15}$ to classify action levels for $\mathrm{HbA}_{1 \mathrm{c}}$. Similarly, blood pressure was considered to be uncontrolled if $\geq 130 / 85 \mathrm{~mm} \mathrm{Hg}$ and further defined using the Joint National Committee 7 (JNC 7) categorizations. ${ }^{16}$ Finally, a LDL-C level of $\geq 100 \mathrm{mg} / \mathrm{dL}$ was considered uncontrolled. ${ }^{16}$

\section{Data Analysis}

We report descriptive characterizations of the 95 eligible clinicians and their patients, and the numbers of patients meeting the control targets for $\mathrm{HbA}_{1 \mathrm{c}}$, blood pressure, and LDL-C. Contingency tables were used to express the relations between the control of $\mathrm{HbA}_{1 \mathrm{c}}$, cardiovascular risk factors, and treatment strategies. Analyses were performed with SAS Versions 8.2 and 9.1. ${ }^{17}$

To determine whether diabetes and cardiovascular outcomes were associated with patient characteristics, clinician characteristics, practice design strategies, or treatment, general linear mixed models (multilevel models) were used for continuous $\mathrm{HbA}_{1 \mathrm{c}}$ levels. Generalized linear mixed models with $\mathrm{HbA}_{1 \mathrm{c}}$, blood pressure, and LDL-C lipid control (controlled or not controlled) as the outcome (logit link) were used to extend the traditional logistic regression model to accommodate the multilevel structure and clustering of patients within physicians (Proc MIXED with GLIMMIX macro). ${ }^{18}$ Variance components were examined at each level to determine whether random effects should be retained at that level (physician/practice). To enhance stability of the models, 
we used a model-building approach that involved determining which patient-level covariates were needed based on clinical or statistical significance (at $P<.15$ ), and then we added level-2 predictors (physician/practice) one at a time. We also calculated the intraclass correlation coefficient for each control variable across the 95 clinicians.

\section{RESULTS}

\section{Clinician and Patient Characteristics}

A total of 141 clinicians volunteered to participate in the study. Of this number, 127 were family physicians, 2 were general practitioners, 5 were general internists, 4 identified themselves as some combination thereof, and 3 were nurse-practitioners. Nine participants practiced in Canada, and 132 practiced in the United States.

Fourteen (10\%) initial clinician volunteers withdrew before subject recruitment began, and 28 (20\%) were unable to enroll any patients during the 15 -month data-collection phase of the study. Of the remaining 99 clinicians, 4 were dropped from the analysis because they enrolled only 1 patient each.

The 95 participating clinicians had an average age of 45.7 years $(\mathrm{SD}, 7.8)$, and most $(71.6 \%)$ were male. They had been in practice an average of 14.6 years (SD, 8.8). The average number of adult patients with diabetes seen by each clinician in a typical month was 32.6 , with $21.2 \%$ of clinicians providing care to more than 40 adult patients with diabetes per month. Practice type varied widely, with $36.8 \%$ of clinicians working in single-specialty groups, $19.0 \%$ in academic settings, $15.8 \%$ in multispecialty groups, $14.7 \%$ in solo practice, and $13.7 \%$ in a combination of settings. Practice location also varied widely; $37.9 \%$ of practices were in large cities with populations of more than 250,000, whereas $21.1 \%$ were in rural areas.

When clinicians who enrolled at least 2 patients ( $n=95$ ) were compared with those who enrolled none or 1 patient $(n=46)$, the 2 groups differed statistically on $4(6.3 \%)$ of 63 survey items: (1) use of patient-held mini-records ( $25 \%$ vs $48 \%, P<.01)$; ( 2 ) use of letters or postcards ( $6 \%$ vs $39 \%, P<.01)$; (3) use of patient registries ( $8 \%$ vs $23 \%, P<.02$; and (4) mean number of adult patients with diabetes seen per month (33 vs $44, P=.04$ ).

For the 92 physicians who enrolled 2 or more patients, their demographic data were compared with data from the AAFP Masterfile of active US members $(32,219)$ reporting time in direct patient care as of February 2001 (the start of patient enrollment and data collection, this comparison does not include the 3 nurse-practitioners). Of the 6 demographic factors on which these comparisons were possible, the 92 study physicians did not differ statistically $(P>.05)$ by sex, practice type, age, and years since medical school. The comparisons were statistically different $(P<.05)$
Table 1. Characteristics of Study Patients $(\mathrm{N}=822)$

\begin{tabular}{|c|c|}
\hline $\begin{array}{l}\text { Patient Sociodemographics } \\
\text { Characteristics* }\end{array}$ & No. (\%) \\
\hline \multicolumn{2}{|l|}{ Age, y } \\
\hline Mean & 59.5 \\
\hline Standard deviation & 13.1 \\
\hline \multicolumn{2}{|l|}{ Ethnicity } \\
\hline Non-Hispanic white & $575(71.4)$ \\
\hline African American & $121(15.0)$ \\
\hline Hispanic & $63(7.8)$ \\
\hline Other and mixed & $46(5.7)$ \\
\hline Sex, male & $358(44.5)$ \\
\hline \multicolumn{2}{|l|}{ Highest level of education } \\
\hline Did not graduate high school & $201(25.4)$ \\
\hline $\begin{array}{l}\text { High school graduate or general } \\
\text { equivalency diploma }\end{array}$ & $343(43.3)$ \\
\hline College or postgraduate training & $248(31.3)$ \\
\hline \multicolumn{2}{|l|}{ Duration of diabetes, $y$} \\
\hline Mean & 9.1 \\
\hline Standard deviation & 8.7 \\
\hline$<5 y$ & $302(39.9)$ \\
\hline $5-10 y$ & $195(25.8)$ \\
\hline $11-20 y$ & $157(20.7)$ \\
\hline$>20 y$ & $103(13.6)$ \\
\hline \multicolumn{2}{|l|}{ Body mass index ${ }^{\dagger}$} \\
\hline$<18.5$, underweight & $8(1.1)$ \\
\hline 18.5-24.9, normal & $81(11.2)$ \\
\hline 25.0-29.9, overweight & $194(26.9)$ \\
\hline 30.0-34.9, obese class I & $204(28.3)$ \\
\hline 35.0-39.9, obese class II & $117(16.2)$ \\
\hline$\geq 40$, obese class III & $118(16.3)$ \\
\hline \multicolumn{2}{|l|}{ Reason for study office visit ${ }^{\dagger \neq}$} \\
\hline Routine diabetes follow-up & $575(70.8)$ \\
\hline Acute problem & $174(21.4)$ \\
\hline Chronic problem, routine & $165(20.3)$ \\
\hline Chronic problem, flare-up & $43(5.3)$ \\
\hline Pre- or postsurgery follow-up & $23(2.8)$ \\
\hline Nonillness care & $59(7.3)$ \\
\hline \multicolumn{2}{|c|}{$\begin{array}{l}\text { Note: Frequencies may be less than the total sample size because of missing } \\
\text { data. Percentages are based on valid observations. }\end{array}$} \\
\hline \multicolumn{2}{|l|}{$\begin{array}{l}\text { * Data from patient survey. } \\
\text { † Data from visit monitoring form. } \\
\text { † More than } 1 \text { reason could have bee }\end{array}$} \\
\hline
\end{tabular}

for percentage of patients on Medicaid, with means of $11.5 \%$ (AAFP) and $15.2 \%$ (study), and for years in practice, with means of 11.3 years (AAFP) and 14.9 years (study), although for the study physicians this variable was measured as "years since residency."

Of the 834 patients who were enrolled in the study, only 822 patients were included in the analysis. Of the 12 that were dropped, 4 were the only patients their clinicians enrolled and 8 had a missing patient questionnaire or visit monitoring form. The characteristics of the 822 adult patients who were included in the analysis are given in Table 1. 


\begin{tabular}{|c|c|c|c|}
\hline Complications and Comorbidities* & No. (\%) & Complications and Comorbidities* & No. (\%) \\
\hline Complications related to diabetes ${ }^{\dagger}$ & & Other comorbid health problems ${ }^{\dagger}$ & \\
\hline Coronary artery disease & $147(18.6)$ & Hypertension & $457(56.7)$ \\
\hline Neuropathy & $146(18.5)$ & Osteoarthritis & $221(27.6)$ \\
\hline Nephropathy & $125(15.8)$ & Chronic low back pain & $188(23.4)$ \\
\hline Retinopathy & $78(9.9)$ & Asthma & $83(10.3)$ \\
\hline Peripheral vascular disease & $78(9.9)$ & Thyroid problems & $82(10.2)$ \\
\hline Foot ulcer/infection & $40(5.1)$ & Congestive heart failure & $52(6.5)$ \\
\hline Other infection & $33(4.2)$ & Chronic obstructive lung disease & $51(6.4)$ \\
\hline Gastroparesis & $29(3.7)$ & & \\
\hline
\end{tabular}

Table 3. Patients Meeting Control Targets for Glycosylated Hemoglobin and Cardiovascular Risk Factors

\begin{tabular}{|c|c|c|}
\hline Control Target* & Frequency & $\begin{array}{l}\text { Percent } \\
\text { of Total }\end{array}$ \\
\hline \multicolumn{3}{|l|}{$\mathrm{HbA}_{1 \mathrm{c}}$} \\
\hline$<7.0 \%$ & 313 & 40.5 \\
\hline $7.0 \%$ to $7.9 \%$ & 217 & 28.1 \\
\hline $8.0 \%$ to $8.9 \%$ & 109 & 14.1 \\
\hline $9.0 \%$ to $9.9 \%$ & 61 & 7.9 \\
\hline$\geq 10.0 \%$ & 72 & 9.3 \\
\hline \multicolumn{3}{|l|}{ Blood pressure: ADA target } \\
\hline $\begin{array}{l}\text { Systolic }<130 \mathrm{~mm} \mathrm{Hg} \text { and diastolic } \\
<85 \mathrm{~mm} \mathrm{Hg}\end{array}$ & 285 & 35.3 \\
\hline \multicolumn{3}{|l|}{ Blood pressure: JNC 7 categories ${ }^{\dagger}$} \\
\hline $\begin{array}{l}\text { Normal (systolic }<120 \mathrm{~mm} \mathrm{Hg} \text { and } \\
\text { diastolic }<80 \mathrm{~mm} \mathrm{Hg} \text { ) }\end{array}$ & 146 & 18.1 \\
\hline $\begin{array}{l}\text { Prehypertension (systolic } 120-139 \mathrm{~mm} \mathrm{Hg} \text { or } \\
\text { diastolic } 80-90 \mathrm{~mm} \mathrm{Hg} \text { ) }\end{array}$ & 452 & 55.9 \\
\hline $\begin{array}{l}\text { Stage } 1 \text { hypertension (systolic 140-159 } \mathrm{mm} \mathrm{Hg} \\
\text { or diastolic } 90-99 \mathrm{~mm} \mathrm{Hg} \text { ) }\end{array}$ & 176 & 21.8 \\
\hline $\begin{array}{l}\text { Stage } 2 \text { hypertension (systolic } \geq 160 \mathrm{~mm} \mathrm{Hg} \text { or } \\
\text { diastolic } \geq 100 \mathrm{~mm} \mathrm{Hg} \text { ) }\end{array}$ & 34 & 4.2 \\
\hline \multicolumn{3}{|l|}{ LDL-C } \\
\hline$<100 \mathrm{mg} / \mathrm{dL}$ & 294 & 43.8 \\
\hline $100-129 \mathrm{mg} / \mathrm{dL}$ & 198 & 29.5 \\
\hline $130-159 \mathrm{mg} / \mathrm{dL}$ & 105 & 15.7 \\
\hline $160-189 \mathrm{mg} / \mathrm{dL}$ & 52 & 7.8 \\
\hline$\geq 190 \mathrm{mg} / \mathrm{dL}$ & 22 & 3.3 \\
\hline \multicolumn{3}{|l|}{ Combined targets } \\
\hline $\mathrm{HbA}_{1 \mathrm{c}}(<7 \%)$ and LDL-C $(<100 \mathrm{mg} / \mathrm{dL})$ & 111 & 16.7 \\
\hline $\begin{array}{l}\mathrm{HbA}_{1 \mathrm{c}}(<7 \%) \text { and blood pressure } \\
\quad(<130 / 85 \mathrm{~mm} \mathrm{Hg})\end{array}$ & 104 & 13.7 \\
\hline $\begin{array}{l}\mathrm{HbA}_{1 \mathrm{c}}(<7 \%) \text { and blood pressure } \\
\quad(<130 / 85 \mathrm{~mm} \mathrm{Hg}) \text { and LDL-C } \\
(<100 \mathrm{mg} / \mathrm{dL})\end{array}$ & 45 & 7.0 \\
\hline \multicolumn{3}{|c|}{$\begin{array}{l}\mathrm{HbA}_{1 \mathrm{c}}=\text { glycosylated hemoglobin; } \mathrm{ADA}=\text { American Diabetes Association; JNC } 7=\text { The Sev- } \\
\text { enth Report of the Joint National Committee on Prevention, Detection, Evaluation, and Treat- } \\
\text { ment of High Blood Pressure; LDL-C = low-density lipoprotein cholesterol. }\end{array}$} \\
\hline \multicolumn{3}{|c|}{$\begin{array}{l}\text { Note: Percentage is based on cases where data were available and provided. Missing data } \\
\text { rates are } 6.1 \% \text { for } \mathrm{HbA}_{1 c}, 1.7 \% \text { for blood pressure, and } 18.4 \% \text { for LDL-C. Data are from visit } \\
\text { monitoring forms. }\end{array}$} \\
\hline \multicolumn{3}{|c|}{$\begin{array}{l}\text { * Based on American Diabetes Association target for adults with type-2 diabetes. }{ }^{14} \\
\text { † Based on the JNC } 7 \text { for blood pressure. }{ }^{16}\end{array}$} \\
\hline
\end{tabular}

Practice Design and Health Care Team Practice design features to enhance diabetes care included the use of diabetes management protocols/flow sheets $(72.6 \%)$, the use of an electronic medical record (29.5\%), and the involvement of a nurse-practitioner or physician's assistant $(21 \%)$. Few clinicians $(8.4 \%)$ used patient registries. The most common health professionals to whom the clinicians referred their diabetic patients included dietitians $(88.4 \%)$, ophthalmologists $(85.8 \%)$, diabetes educators $(71.6 \%)$, podiatrists $(58.9 \%)$, and endocrinologists $(42.1 \%)$. These figures refer to health professionals that study clinicians reported they routinely used (within the practice or by referral) in the care of patients with type 2 diabetes, not actual referral rates.

\section{Comorbid Health Problems}

Table 2 displays the diabetes-related complications and other comorbid health problems reported by patients in the study. Nearly one half $(47.5 \%)$ of the patients reported having had at least 1 diabetes-related complication, with coronary artery disease, neuropathy, and nephropathy the most common.

\section{Clinical Measures of Diabetes and Control Targets}

Table 3 displays the control of $\mathrm{HbA}_{1 \mathrm{c}}$, blood pressure, and LDL-C for patients in the study (data from the visit monitoring form). The $\mathrm{HbA}_{1 \mathrm{c}}$ value was $<7 \%$ for $313(40.5 \%)$ patients, and the mean value was $7.6 \%$ (SD, 1.73). Using the ADA target of $130 / 85 \mathrm{~mm}$ $\mathrm{Hg}$ for blood pressure, 285 (35.3\%) patients had adequate blood pressure control. For LDL-C, 294 (43.8\%) patients had levels 


\begin{tabular}{lc|}
\hline \multicolumn{2}{|l}{ Table 4. Diabetes and Cardiovascular Medications } \\
Used by Patients With Type 2 & Diabetes (N = 822) \\
\hline Drug Class or Description & No. (\%) \\
\hline Insulin & $187(22.7)$ \\
Oral diabetes medications & \\
Biguanide & $439(54.1)$ \\
Sulfonylurea & $440(53.3)$ \\
Alpha-glucosidase inhibitor & $14(1.7)$ \\
Thiazolidinedione & $225(27.4)$ \\
Antihypertensives & $613(74.6)$ \\
Aspirin & $289(35.7)$ \\
Any lipid-lowering drug & $481(58.5)$ \\
ACE Inhibitor or ARB & $469(57.1)$ \\
\hline ACE = angiotensin-converting enzyme inhibitor; ARB $=$ angiotensin receptor \\
blocker. \\
Note: Data are from visit monitoring form. \\
\hline
\end{tabular}

$<100 \mathrm{mg} / \mathrm{dL}$, indicating adequate control. Finally, when the 3 control targets were considered together, 45 (7.0\%) met all 3 targets.

\section{Treatment}

Treatment data were obtained from the visit monitoring form. Table 4 reports the specific diabetes and cardiovascular medications or classes of medications that the patients used. Nearly 3 in 4 patients were taking antihypertensive medications. More than one half were taking angiotensin-converting enzyme (ACE) inhibitors or angiotensin-receptor blockers (ARBs), and about one third were taking aspirin. More than one half were taking a lipid-lowering medication.

Table 5 shows the relationship between $\mathrm{HbA}_{1 \mathrm{c}}$ level and the diabetes treatment strategies, including oral medications and insulin. Overall, $88.7 \%$ of patients were being treated with oral medications and/or insulin. The use of oral medications and insulin was more common among patients with $\mathrm{HbA}_{1 \mathrm{c}}$ levels ranging from $7 \%$ to $8 \%$ than among patients whose levels were $<7 \%$.
Among patients with $\mathrm{HbA}_{1 \mathrm{c}}$ levels > $\%$, 97.4\% were treated with oral medications and/or insulin, and nearly one half $(47.8 \%)$ were treated with at least 2 oral medications. Slightly more than one third (34.2\%) of these patients were taking insulin.

To control cardiovascular risk factors (Table 6), $74.6 \%$ of patients were given prescriptions for an antihypertensive medication. There were 117 patients (14.5\% of the total) who had poor blood pressure control and were receiving lifestyle change management only or no active treatment. There were 166 patients (24.7\% of the total) with elevated LDL-C levels who received only lifestyle change management or no active treatment.

\section{Factors Associated With Control of $\mathrm{HbA}_{1 \mathrm{c}}$ and Cardiovascular Risk Factors}

Three of 4 variance components for physicians were significant at $P<.05$, with intraclass correlation coefficients of $0.022\left(\mathrm{HbA}_{1 \mathrm{c}}\right.$ as a continuous variable $), 0.045$ ( $\mathrm{HbA}_{1 \mathrm{c}}$ controlled or not controlled), 0.041 (blood pressure controlled or not controlled), and 0.074 (LDLC controlled or not controlled), suggesting that it was necessary to use methods appropriate for clustered data. Results from multilevel models showing associations with these 4 control outcomes are given in Tables 7 and 8 . The only patient-level factor associated with $\mathrm{HbA}_{1 \mathrm{c}}$ was ethnicity (poorer control for African American, Hispanic, and other patients, compared with white patients). Of the clinician-level characteristics, patients cared for in academic settings, by solo practitioners, and in multispecialty groups had higher $\mathrm{HbA}_{1 \mathrm{c}}$ values than patients cared for in single-specialty groups. The only significant practice design feature was involvement of nurse-practitioners or physician's assistants, where involvement was associated with lower $\mathrm{HbA}_{1 \mathrm{c}}$ values. Finally, treatment was strongly related to $\mathrm{HbA}_{1 \mathrm{c}}$ levels, where more aggressive treatment was associated with higher $\mathrm{HbA}_{1 \mathrm{c}}$ levels. Results for the continuous $\mathrm{HbA}_{1 \mathrm{c}}$

\section{Table 5. Relation Between Treatment Modality and Control for Adult Primary Care Patients} with Type 2 Diabetes as Measured by $\mathrm{HbA}_{1 \mathrm{c}}$ Level

\begin{tabular}{|c|c|c|c|c|c|c|}
\hline $\begin{array}{l}\text { Glycosylated } \\
\text { Hemoblobin Level }\end{array}$ & $\begin{array}{c}\text { Diet Only } \\
\text { n }(\%)\end{array}$ & $\begin{array}{c}1 \text { Oral } \\
\text { Medication } \\
\text { n (\%) }\end{array}$ & $\begin{array}{c}2 \text { Oral } \\
\text { Medications } \\
\text { n (\%) }\end{array}$ & $\begin{array}{c}1 \text { Oral } \\
\text { Medication } \\
\text { and Insulin } \\
\text { n (\%) }\end{array}$ & $\begin{array}{l}\text { Insulin } \\
\text { n (\%) }\end{array}$ & $\begin{array}{c}\text { Row Totals } \\
\text { n (\%) }\end{array}$ \\
\hline $\mathrm{HbA}_{1 \mathrm{c}}<7 \%$ & 55 (17.6) & $118(37.7)$ & 100 (31.9) & $26(8.3)$ & $14(4.5)$ & $313(40.5)$ \\
\hline $\mathrm{HbA}_{1 \mathrm{c}} 7 \%-8 \%$ & $26(11.3)$ & 72 (31.2) & 78 (33.8) & $36(15.6)$ & $19(8.2)$ & 231 (29.9) \\
\hline $\mathrm{HbA}_{1 \mathrm{c}}>8 \%$ & $6(2.6)$ & 35 (15.4) & $109(47.8)$ & $52(22.8)$ & $26(11.4)$ & $228(29.5)$ \\
\hline Column totals & 87 (11.3) & $225(29.1)$ & $287(37.2)$ & $114(14.8)$ & $59(7.6)$ & 772 \\
\hline
\end{tabular}




\begin{tabular}{|c|c|c|c|}
\hline $\begin{array}{l}\text { Cardiovascular } \\
\text { Risk Factors }\end{array}$ & $\begin{array}{l}\text { Taking } \\
\text { Medication* } \\
\text { n (\%) }\end{array}$ & $\begin{array}{l}\text { Lifestyle Change } \\
\text { or Not Treated } \\
n(\%)\end{array}$ & $\begin{array}{c}\text { Row Totals } \\
\text { n (\%) }\end{array}$ \\
\hline \multicolumn{4}{|l|}{ Blood pressure } \\
\hline$<130 / 85 \mathrm{~mm} \mathrm{Hg}$ & $197(69.1)$ & $88(30.9)$ & $285(35.3)$ \\
\hline$\geq 130 / 85 \mathrm{~mm} \mathrm{Hg}$ & $406(77.6)$ & $117(22.4)$ & $523(64.7)$ \\
\hline Column totals & $603(74.6)$ & $205(25.4)$ & 808 \\
\hline \multicolumn{4}{|l|}{ LDL-C } \\
\hline$<100 \mathrm{mg} / \mathrm{dL}$ & $200(68.3)$ & $93(31.7)$ & $293(43.7)$ \\
\hline$\geq 100 \mathrm{mg} / \mathrm{dL}$ & $212(56.1)$ & $166(43.9)$ & $378(56.3)$ \\
\hline Column totals & $412(61.4)$ & $259(38.6)$ & 671 \\
\hline \multicolumn{4}{|c|}{ LDL-C = low-density lipoprotein cholesterol } \\
\hline \multicolumn{4}{|c|}{$\begin{array}{l}\text { Note: Data are expressed as frequencies and percentages (in parentheses); the percentages in the } \\
\text { "Row Totals" are row percentages and those in the "Column totals" are column percentages. Data } \\
\text { from visit monitoring form. }\end{array}$} \\
\hline \multicolumn{4}{|c|}{$\begin{array}{l}\text { * Antihypertensive medications for blood pressure control, and lipid-lowering medications for low- } \\
\text { density lipoprotein cholesterol control. } \\
\text { t Totals vary because of missing data. }\end{array}$} \\
\hline
\end{tabular}

models and models predicting poor control were generally similar.

Few patient-level variables were associated with poor control of blood pressure or LDL-C. Older patients and those with less than a high school education were more likely to have poor control of blood pressure. African American patients were more likely to have poor LDL-C control than white patients. The only significant clinician characteristic related to poor control of blood pressure was solo practitioner compared with single-specialty groups. No clinician characteristics were associated with control of LDL-C. Finally, none of the practice design features or treatment were associated with control of blood pressure or LDL-C.

\section{DISCUSSION}

We believe this cross-sectional study is the first published that describes how primary care clinicians (mostly family physician members of PBRNs) from across the United States manage patients with type 2 diabetes and some of the results that are achieved. Our study found that these patients have moderately advanced and complex disease of prolonged duration, as well as high rates of diabetes-related complications, obesity, and other comorbid conditions. Other studies in the literature addressing similar issues are based on retrospective analyses of large databases ${ }_{,}{ }^{19}$ are limited to academic medical centers, ${ }^{20}$ or involve experiments designed to test specific treatment interventions, ${ }^{21}$ and may have different selection biases than would a primary care practice-based study of unselected patients.

We find that these patients are being treated with glucose-lowering medications, antihypertensives, and lipid-lowering agents by experienced primary care clinicians, who see many patients with type 2 diabetes in their practices. These clinicians use other health care professionals, including dietitians and diabetes educators, to help manage their patients and give them written educational materials on diabetes.

Despite the intensity of diabetes care being provided, only a modest number (40.5\%) of patients actually achieved the established target for glycemic control, with a group mean $\mathrm{HbA}_{1 \mathrm{c}}$ of $7.6 \%$. These results are similar to those from an analysis of a sample of patients with type 2 diabetes from the NHANES III study conducted in 1991-1994 $\left(\mathrm{HbA}_{1 \mathrm{c}}<7 \%\right.$ in $42.3 \%$ of patients, mean value $7.8 \%)^{19}$ and are better that those reported in a recent retrospective study of general medicine and endocrinology clinics in academic medical centers from 2000-2002 $\left(\mathrm{HbA}_{1 \mathrm{c}}<7 \%\right.$ in $34 \%$ of patients, mean value $7.9 \%-8.1 \%){ }^{20}$

There are a number of potential explanations for this suboptimal level of glycemic control in our study patients. While "clinical inertia" and underprescribing of oral hypoglycemic medications and/or insulin may contribute to this problem, ${ }^{21-24}$ it is noteworthy that patients with higher $\mathrm{HbA}_{1 \mathrm{c}}$ levels were more likely to be on more than 1 oral hypoglycemic agent and/or insulin than were patients whose $\mathrm{HbA}_{1 \mathrm{c}}$ levels were at or below target. This finding may well reflect the reality that the longer the duration of disease, the more difficult it is to maintain glycemic control, and the greater the need for multiple medications, as shown in the UK Prospective Diabetes Study study. ${ }^{25}$ Suboptimal patient compliance is another potential explanation; many factors can affect patient compliance, including the patient's relative utilities or preferences for the short-term discomfort and side effects of treatment compared with the potential long-term benefits of decreased morbidity and mortality from diabetic complications.

Even fewer patients achieved the blood pressure and LDL-C target levels. Only 35.3\% were at or below target blood pressure recommended by the ADA, with only $74 \%$ below the JNC 7 level for stage 1 hypertension (140/90 mm Hg). Only $50.1 \%$ of type 2 diabetics in the NHANES III sample had blood pressures below $140 / 90 \mathrm{~mm} \mathrm{Hg} .{ }^{19}$ In our study, $43.7 \%$ of patients achieved LDL-C target levels of $100 \mathrm{mg} / \mathrm{dL}$ compared with $15.4 \%$ of patients in the NHANES III study ${ }^{19}$ and $49.4 \%$ of diabetic patients from the Vermont Diabetes Information System Trial. ${ }^{26}$ We found that it was even 
harder to achieve target levels simultaneously for multiple risk factors. We believe that this finding reflects the enormous complexity involved in controlling multiple risk factors in patients with diabetes. ${ }^{27}$

Few patient factors, clinician characteristics, or practice design strategies were associated with the glycemic or cardiovascular risk factor control outcomes The adverse impact of minority ethnicity status on $\mathrm{HbA}_{1 \mathrm{c}}$ and LDL-C levels may constitute examples of health disparities in minority populations. The finding that more aggressive treatment with diabetic medications was associated with higher $\mathrm{HbA}_{1 \mathrm{c}}$ values in the multilevel analysis again suggests the possibility that glycemic control becomes more difficult with time despite the use of multiple diabetic medications, including insulin.

These challenges underline the need for improving the systems that support the care of patients with chronic diseases, ${ }^{7}$ including the use of disease registries for tracking patients, ${ }^{28,29}$ along with specific clinically important parameters for managing the disease of interest. Only $8.4 \%$ of practices in our study reported using registries, suggesting an opportunity for improving active outreach to patients who have not reached target levels of risk factor control. Reengineering is supported by the 2004 Future of Family Medicine Report, ${ }^{30}$ which strongly recommended reorganizing primary care practices to provide improved, proactive, patient-centered, population-based chronic care

The limitations of the study are inherent in practice-based research and cross-sectional descriptive work of this kind. First, the physicians that volunteered to participate may have differed from the larger macrocosm of practicing primary care physicians. Second, we were not able to assess the degree to which the primary care clinicians were able to recruit patients consecutively. Although $52(55 \%)$ clinicians enrolled a minimum of 10 patients, the other clinicians enrolled between 2 and 9. Third, the accuracy of the medical record data cannot be guaranteed. In addition, the laboratory 
values were not standardized across practice sites, and blood pressure readings were based on a single reading. Only patients able to speak and read English were eligible for the study. This study was not able to address the spectrum of diabetes management for non-English speaking patients. Similarly, we did not assess health literacy level, although more than $25 \%$ of the patients were not high school graduates. Finally, it should be noted that most of the clinicians in the study were fam-

\begin{tabular}{|c|c|c|}
\hline Domain/Variable & $\begin{array}{l}\text { Model Predicting } \\
\text { Blood Pressure } \\
>130 / 85 \mathrm{~mm} \text { Hg } \\
(\mathrm{n}=699) \\
\text { OR }(95 \% \mathrm{Cl})\end{array}$ & $\begin{array}{l}\text { Model Predicting } \\
\text { LDL-C > } 100 \mathrm{mg} / \mathrm{dL} \\
(\mathrm{n}=582) \\
\text { OR }(95 \% \mathrm{Cl})\end{array}$ \\
\hline \multicolumn{3}{|l|}{ Patient characteristics } \\
\hline Age & $1.03(1.02-1.05)^{*}$ & 0.99 (0.98-1.01) \\
\hline \multicolumn{3}{|l|}{ Ethnicity (white is reference group) } \\
\hline African American & $1.62(0.96-2.76)$ & $1.86(1.08-3.20)^{*}$ \\
\hline Hispanic & $0.72(0.39-1.32)$ & $1.31(0.69-2.49)$ \\
\hline Other & $0.57(0.27-1.20)$ & $1.16(0.50-2.69)$ \\
\hline Sex, male & $0.79(0.57-1.12)$ & $0.81(0.57-1.16)$ \\
\hline \multicolumn{3}{|l|}{$\begin{array}{l}\text { Education (college graduate } \\
\text { is reference group) }\end{array}$} \\
\hline Not a high school graduate & $1.63(1.02-2.63)^{*}$ & $0.83(0.51-1.36)$ \\
\hline High school graduate or GED & $1.44(0.98-2.10)$ & $0.90(0.60-1.36)$ \\
\hline Duration of diabetes & $0.99(0.97-1.01)$ & $0.99(0.97-1.01)$ \\
\hline \multicolumn{3}{|l|}{ Provider characteristics ${ }^{\dagger}$} \\
\hline Years in practice & $1.02(1.00-1.05)$ & $0.99(0.96-1.01)$ \\
\hline Sex, male & $1.55(1.00-2.40)$ & $0.86(0.53-1.39)$ \\
\hline $\begin{array}{l}\text { No.of patients with diabetes } \\
\text { seen in typical month }\end{array}$ & $1.01(1.00-1.01)$ & $1.00(0.99-1.01)$ \\
\hline \multicolumn{3}{|l|}{$\begin{array}{l}\text { Practice type (single specialty } \\
\text { is reference group) }\end{array}$} \\
\hline Academic setting & $0.90(0.51-1.59)$ & $0.75(0.41-1.36)$ \\
\hline Solo practice & $2.12(1.14-3.94)^{*}$ & $0.57(0.30-1.06)$ \\
\hline Multispecialty group & $1.13(0.63-2.00)$ & $1.33(0.71-2.49)$ \\
\hline Combination of settings & $0.81(0.45-1.46)$ & $1.12(0.58-2.16)$ \\
\hline \multicolumn{3}{|l|}{ Practice design features ${ }^{\dagger}$} \\
\hline Flow sheets & $0.70(0.44-1.12)$ & $1.45(0.91-2.33)$ \\
\hline Electronic medical record & $0.91(0.59-1.39)$ & $1.09(0.68-1.72)$ \\
\hline $\begin{array}{l}\text { Involvement of nurse-practitioners } \\
\text { or physician's assistants }\end{array}$ & $1.35(0.83-2.22)$ & $1.15(0.69-1.92)$ \\
\hline Patient registries & $0.94(0.47-1.89)$ & $1.37(0.62-3.03)$ \\
\hline Dietician & $0.85(0.46-1.56)$ & $0.61(0.32-1.19)$ \\
\hline Diabetes educators & $0.93(0.53-1.61)$ & $1.18(0.66-2.08)$ \\
\hline Endocrinologists & $1.16(0.78-1.72)$ & $1.00(0.66-1.52)$ \\
\hline \multicolumn{3}{|l|}{ Treatment } \\
\hline $\begin{array}{l}\text { Any antihypertensive or } \\
\text { lipid-lowering medication }\end{array}$ & $1.37(0.93-2.00)$ & $0.71(0.49-1.03)$ \\
\hline \multicolumn{3}{|c|}{$\begin{array}{l}\mathrm{CI}=\text { confidence interval; } \mathrm{LDL}-\mathrm{C}=\text { low-density lipoprotein cholesterol; GED }=\text { general equivalency diploma } \\
\text { Note: In models predicting poor control, an odds ratio that does not include } 1.0 \text { is significant at } P<.05 \text {. } \\
\text { * Estimate significant at } P<.05 \text {. } \\
\dagger \text { Clinician characteristics and practice design features were entered one at a time after all patient charac- } \\
\text { teristics and treatment are in the model. }\end{array}$} \\
\hline
\end{tabular}

ily physicians, and there may be differences in practice style across specialties we are not able to address.

In summary, patients with type 2 diabetes are commonly cared for in primary care settings and have a substantial burden of diabetes-related comorbidity. Whereas treatment of hyperglycemia is somewhat successful, control of cardiovascular risk factors is poor and remains a considerable challenge. Further research will help us better understand the complex process-to-outcome relationships in diabetes care. The structures and processes of primary care practice will require urgent changes that support a more proactive, population-based, patient-centered approach.

\section{To read or post commentaries in response to this article, see it online at http://www. annfammed.org/cgi/content/full/4/1/23.}

Key words: Diabetes mellitus, type 2; primary health care; comorbidity; practice-based research

Submitted April 12, 2005; submitted, revised, October 25, 2005; accepted October 31, 2005.

Findings from this study were presented in part at annual meetings of the North American Primary Care Research Group, October 14, 2001, October 18, 2003, October 20, 2003, and October 17, 2005.

Funding support: Eli Lilly and Company provided funding for this project through an unrestricted research grant. The practice-based research networks that participated in this study were supported by grants from the Agency for Healthcare Research and Quality (grant No. P2O HS11182 to the AAFP, and grant No. P2O HS11187 to Baylor College of Medicine), and a grant from the Bureau of Health Professions of the Health Resources and Services Administration to Baylor College of Medicine (grant No. D12 HP00042).

Acknowledgments: Appreciation is expressed to John M. Hickner, MD, MS; Wilson Pace, MD; and Herbert F. Young, MD, MA, of the AAFP for their continuous support and guidance in the execution of this project. In addition, appreciation is expressed to those individuals involved in the data collection, management, and analysis for this project, including the following: Jennifer A. Kappas, BA; Thomas V. Stewart, BA; Deborah G. Graham, MSPH, AAFP; Grace, M. Kuo, PharmD; Jeffrey R. Steinbauer, MD; Irene Easling, DrPH; Kristin Weidman, BA; Julie Thompson, $\mathrm{PhD}(\mathrm{c}), \mathrm{RN}, \mathrm{CNOR}$, Harris County Hospital District; Anthony J. Greisinger, PhD, Kelsey Research Foundation; SPUR-Net; Charmaine LeBlanc, Jennifer L. Fisher, MAFPRN; Walter L. Calmbach, MD, director of the network; Anna Jenkins, TAFP R-Net. Finally, we thank Pamela Paradis Tice, ELS(D), and Elizabeth Staton (NRN staff) for editing and critical feedback on the manuscript. 
Study participants: The following network clinicians participated in this study: Nageeb Girgis Abdalla, MD; Bryan Alton, MD; Vicki Anderson, MD; Douglas Ballan, MD; Ashley Brewer, RN; Cindy Carlson, RN; Dana L. Clark, MD; Robert Clark, MD; Peggy Cole, RN; Jane E. Corboy, MD; Jane Cordell, RN; Howard Corren, MD; Steven Crane, MD; Michael A. Crouch, MD, MSPH; Larry Davis, MD; Melissa Devalon, MD; Gail Disney, LPN; Daniel Doyle, MD; Sabrina M. Echols-Elliott, MD; Andrew C. Eisenberg, MD; Scott Ekdahl, DO; Rodney Erickson, MD; John Farmer, DO; Robert Farron, DO; David Flinders, MD; Sandra Florence, RN; Tracy Frandsen, MD; Edward Friedler, MD; Edward M. Gardiner, MD; Joanne Gerrard; Joette Gracia-Trujillo, MD; Katherine Gutherie, MD; Michael Hartsell, MD; Meg Hayes, MD; Jackie Hodgson, RN; Barry Hoffman; James Horton, MD; David Johnson, MD; Terrie Johnson; Raj Kachoria, MD; Gerald Kenefick, MD; Timothy Komoto, MD; Daria Kovarikova, MD; Kimberly Krohn, MD; Kaparaboyna Ashok Kumar, MD; Dennis LaRavia, MD; Tomas Guiab Lumicao Jr MD; Leah Raye Mabry, MD; Steven Mattson, MD; John McCabe, MD; James McCann, MD; Adam Miner, MD; Bob Moore, PhD; Richard Myers, MD; Charles North, MD; A. Orzano, MD; Afreen Pappa, MD; Diane Poehlman; J. Pontious, MD; William Price, MD; Tom Raff, MD; Wayne Reynolds, DO; Lori Ricke, MD; John C. Rogers, MD; David Ross, MD; Andrew Selinger, MD; John Sherrod, MD; Linda Marie Siy, MD; Stephen Staten, MD; Linda Stewart, MD; Jeffrey R. Steinbauer, MD; Sheri J. Talley, MD; Roslyn Taylor, MD; J. Voorhees, MD; Darryl White, MD; Simon N. Whitney, MD, JD; Paul Williams, DO; Mary Willis, RN; Keith Wixtrom, MD; Michael Wooten, MD; Muriel Young, RN.

\section{References}

1. Woodwell DA, Cherry DK. National Ambulatory Medical Care Survey: 2002 Summary. Advance data from vital health statistics. Hyattsville, Md: National Center for Health Statistics; 2004. No. 346.

2. Jaen $C R$, Stange $K C$, Nutting PA. Competing demands of primary care: a model for the delivery of clinical preventive services. J Fam Pract. 1994;38:166-171.

3. Jaen CR, Stange KC, Tumiel LM, Nutting P. Missed opportunities for prevention: smoking cessation counseling and the competing demands of practice. J Fam Pract. 1997;45:348-354.

4. Nutting PA, Baier M, Werner JJ, et al. Competing demands in the office visit: what influences mammography recommendations? J Am Board Fam Pract. 2001;14:352-361.

5. Nutting PA, Rost K, Smith J, Werner JJ, Elliot C. Competing demands from physical problems: effect on initiating and completing depression care over 6 months. Arch Fam Med. 2000;9:1059-1064.

6. Hofer TP, Zemencuk JK, Hayward RA. When there is too much to do: how practicing physicians prioritize among recommended interventions. J Gen Intern Med. 2004;19:646-653.

7. Wagner EH, Austin BT, Davis C, et al. Improving chronic illness care: translating evidence into action. Health Aff (Millwood). 2001;20:64-78

8. Lindbloom EJ, Ewigman BG, Hickner JM. Practice-based research networks: the laboratories of primary care research. Med Care. 2004;42: |II45-III49.

9. Nutting PA. Practice-based research networks: building the infrastructure of primary care research. J Fam Pract. 1996;42:199-203.

10. Nutting PA, Baier M, Werner JJ, et al. Practice patterns of family physicians in practice-based research networks: a report from ASPN. Ambulatory Sentinel Practice Network. J Am Board Fam Pract. 1999;12:278-284.
11. Nutting PA, Beasley JW, Werner JJ. Practice-based research networks answer primary care questions. JAMA. 1999;281:686-688.

12. Peterson KA, Vinicor F. Strategies to improve diabetes care delivery. J Fam Pract. 1998;47:S55-62.

13. National Committee for Quality Assurance. Diabetes Quality Improvement Project initial measure set (final version). Available at: http:/l www.ncqa.org/DPRP/dqip2.htm. Accessed: March 21, 2005.

14. American Diabetes Association. Standards of medical care for patients with diabetes mellitus. Diabetes Care. 2003;26(Suppl 1):S33S50.

15. Parnes BL, Main DS, Dickinson LM, et al. Clinical decisions regarding $\mathrm{HbA}_{1 \mathrm{c}}$ results in primary care: a report from CaReNet and HPRN Diabetes Care. 2004;27:13-16.

16. Chobanian AV, Bakris GL, Black HR, et al. The Seventh Report of the Joint National Committee on Prevention, Detection, Evaluation, and Treatment of High Blood Pressure: the JNC 7 report. JAMA. 2003;289:2560-2572.

17. SAS(R) Version 8.2 [computer program]. Cary, NC: SAS Institute; 2000.

18. Littell R, Milliken GA, Stroup W/W, Wolfinger RD. SAS System for Mixed Models. Cary, NC: SAS Institute; 1996.

19. Harris MI. Health care and health status and outcomes for patients with type 2 diabetes. Diabetes Care. 2000;23:754-758.

20. Grant RW, Buse JB, Meigs JB. Quality of diabetes care in U.S. academic medical centers: low rates of medical regimen change. Diabetes Care. 2005;28:337-442.

21. Phillips LS, Branch WT, Cook CB, et al. Clinical inertia. Ann Intern Med. 2001;135:825-834.

22. Shah BR, Hux JE, Laupacis A, Zinman B, van Walraven C. Clinical inertia in response to inadequate glycemic control: do specialists differ from primary care physicians? Diabetes Care. 2005;28:600-606.

23. Ziemer DC, Miller CD, Rhee MK, et al. Clinical inertia contributes to poor diabetes control in a primary care setting. Diabetes Educ. 2005;31:564-571.

24. Grant RW, Cagliero E, Dubey AK, et al. Clinical inertia in the management of Type 2 diabetes metabolic risk factors. Diabet Med. 2004;21:150-155.

25. Intensive blood-glucose control with sulphonylureas or insulin compared with conventional treatment and risk of complications in patients with type 2 diabetes (UKPDS 33). UK Prospective Diabetes Study (UKPDS) Group. Lancet. 1998;352:837-853.

26. Kennedy AG, MacLean CD, Littenberg B, Ades PA, Pinckney RG. The challenge of achieving national cholesterol goals in patients with diabetes. Diabetes Care. 2005;28:1029-1034.

27. Peterson KA. Diabetes management in the primary care setting: summary. Am J Med. 2002;113(Suppl 6A):36S-40S.

28. Grant RW, Hamrick HE, Sullivan CM, et al. Impact of population management with direct physician feedback on care of patients with type 2 diabetes. Diabetes Care. 2003;26:2275-2280.

29. Grant RW, Cagliero E, Sullivan CM, et al. A controlled trial of population management: diabetes mellitus: putting evidence into practice (DM-PEP). Diabetes Care. 2004;27:2299-2305.

30. Martin JC, Avant RF, Bowman MA, et al. The future of family medicine: a collaborative project of the family medicine community. Ann Fam Med. 2004;2(Suppl 1):S3-S32. 